\title{
Determinants of News Selection in the Ghanaian Print Media: A Study of the Daily Graphic
}

\section{Isaac Nunoo, University of Ghana, Ghana}

\begin{abstract}
This article discusses the criteria that govern the selection of news in the print media (in Ghana). The article focused particularly on the front page news of the Daily Graphic. The study also assesses what informs the choice of certain news items over others and why some news items are presented prominently on the front page over others. Three methods were used in this study: a survey, content analysis and in-depth interviews. Seventy-two editions of the Daily Graphic and in all, 202 news items were content analysed. The study found that although news values are vital in news selectivity, the Daily Graphic does not use news values as the sole criterion for news selection. What is important is whether a particular news story is in the interest of the public and that it has a high range. Thus, the consequence of such a news story affects the majority of Ghanaians. The finding also suggest that news values as criteria for news selection by the media in the West and replicated by African media should be given a second look.
\end{abstract}

Keywords: news values, gatekeeping, news selection, newsworthiness, news prominence 


\section{Introduction}

News selection has always been an integral part of communication research. While it seems to be beyond dispute that selection has to take place in order to reduce the complexity of the process of collecting and assembling of news for distribution, 'the criteria for the process are subject of a continuing debate' (Eilders, 1996: 1). One of the research traditions concerned with the problem of news selection is news value research which is not common in African media scholarship. Media and communication scholars and practitioners concede that the news stories which are eventually broadcast or published go through a gatekeeping process during which journalists; copy readers and editors assess their newsworthiness using news values. During this process, Shoemaker (1991: 2) says that the news gates which are different decision-making points in a communication channel open, close or are left ajar for certain news items. News selection takes place irrespective of the medium used - whether print or electronic. Kunczik (1988) traces the history of gatekeeping in terms of news values or criteria by which news is selected. Kunczik concludes that in 1676 Christian Weise advocated news values selection based on strict differentiation between truth and falsehood.

In a classical study, Galtung and Ruge (1965) proposed a list of news values that can be used to assess the newsworthiness of news items. By far, the most commonly cited list of news values is that of Galtung and Ruge (1965; Harcup and O’Neill 2001 cited in Brighton and Foy, 2007). Galtung and Ruge’s 12 criteria are as follows: frequency, threshold, unambiguity, meaningfulness, unexpectedness, continuity, compositional balance, elite nations, elite people, reference to persons and reference to something negative. While in the West studies on news values and gatekeeping have been conducted by media researchers like Eilders (1996; 2006); Shoemaker (2006); O’Neil and Harcup (2001) and Peterson (1979), in Africa and Ghana in particular, not much has been done. That notwithstanding, there has been vast improvement in the media of all kinds selecting and offering news to Africans and for that matter Ghanaian consumers.

The Daily Graphic which has become synonymous with the newspaper provides ideas and information to the majority of newspaper readers, especially the elite. It is therefore important to assess what informs the choice of certain news items over others and why some news items are presented prominently on the front page over others since in the opinion of Reisner (1992: 971), the front page of a newspaper is the most important page. 
The article also discusses the gatekeeping and news values theories that have in most cases governed editors' selection of news items for their front page stories (Donohue et al. 1972).

\section{A Brief History of the Print Media in Ghana}

The history of the press in Ghana has been chequered and marred by decades of political and economic quagmires. Like the press in many African countries, the Ghanaian press abound with instances of state interference in private newspaper publishing. For example, The Pioneer was banned for some time in the 1960s and 1970s by the Convention People's Party led by Nkrumah and the National Liberation Council led by Acheampong respectively. The Legon Observer, the Standard, the Christian Messenger and the Echo have all suffered from one political persecution or the other. As was the culture of the press in most African countries in the colonial era, the Ghanaian media played a pivotal role in the crusade against colonialism. After Ghana's independence, the media became the vanguards of opposition to dictatorial rule. However, according to Gadzekpo (2009), the media were also ineffective in their role as the watchdogs over society and political bandits. The media often functioned "as tools of the succession of military regimes which ruled the country from the mid-1960s through the 1970s and 1980s (Gadzekpo, 2009: 89).

The first newspaper published in Ghana was The Royal Gold Coast Gazette and Commercial Intelligencer. It was published from 1822 to 1824 by Sir Charles McCarthy, governor of the British Gold Coast settlements. This was followed by The Accra Herald which was published by Charles Bannerman in 1857. Bannerman's hand-written newspaper was the pioneer of African-owned and edited newspapers in the Gold Coast. After 16 years of survival other indigenous newspapers emerged. Among those newspapers were the Gold Coast Times, Western Echo, Gold Coast Assize, Gold Coast News, Gold Coast Aborigines, Gold Coast Chronicle, Gold Coast People, Gold Coast Independent, and Gold Coast Express (Hasty 2002).

Nkrumah established the Guinea Press under which he introduced the state-owned Ghanaian Times in 1958. Nkrumah bought the Daily Graphic and the Mirror in 1962. The newspaper scene, therefore, became state dominated by the time Nkrumah was overthrown in a military coup in 1966. 
The Fourth Republican Constitution provided an opportunity for media pluralism and the private media began to rise again. Freedom of expression and media protection are enshrined in the 1992 Constitution. The National Media Commission was established with the chief task of insulating state media from governmental control and ensuring high journalistic quality. However, as Kakari (1994: 20 cited in Gadzekpo, 2009: 97) notes, 'in the early years of re-democratisation, the unfettered private press were adjudged as playing a role expected of the independent media under a libertarian, pluralist constitutional system of government; namely [...] serving as watchdogs of accountability.' The content of a number of newspapers fell far short of journalistic standards with some of them publishing outright fictitious stories against public officials and Cabinet members (Kumado, 1995 cited in Gadzekpo, 2009: 98). Like the media in other African countries like South Africa, Nigeria, Malawi and Zambia, the goodwill the Ghanaian media have enjoyed in the Fourth Republican Constitution continues today.

\section{The Daily Graphic}

The Daily Graphic found itself on the news stand on 2nd October, 1950 as one of a chain of newspapers owned by private interest, the Daily Mirror Group of London. The Daily Graphic and Mirror were not an indigenous effort like the Accra Evening News, Gold Coast Chronicle and The Accra Herald. Unlike the local press, the Daily Graphic had access to transnational capital, to modern technology, ran a more efficient business organisation, and demonstrated better journalistic expertise (Hasty 2002). The Daily Graphic has carved out a certain niche market based on its distinctive 'house style’ (Hasty 2006). The Daily Graphic has the largest nationwide readership which includes elites who influence government decisions and also make national policies. Though a state-owned newspaper, the Daily Graphic still operates as an independent newspaper. Appointment of the Board Chairman and the Board Members is however provided for in the Constitution of Ghana and it is done by the National Media Commission in conjunction with the Civil Services Secretariat.

Even though, a cursory look at the front page content of the paper suggests the use of the inverted pyramid, the journalists and the editors are also informed by other factors such as ‘national security, [one’s] condition, [...] personal relationship with sources of news' (Hasty 2006) and public interest. Thus, apart from the universal factors of newsworthiness (proximity, newness, controversy, prominence etc.), the Daily Graphic considers other issues 
that border on national security, peace and unity in selecting news for publication. Its content includes current affairs, politics, economic issues and foreign news. What is published in the newspaper is carefully chosen during a daily editorial meeting attended by top editors. The editors assess the newsworthiness of each news item and which news item to give high prominence to. What is finally given to the Ghanaian consumer is a product of an editorial decision.

\section{Gatekeeping}

The gatekeeping theory is of the view that several pressures determine the passage of certain news items through the news gates. These pressures, which are known as forces, range from micro (individual forces) to macro level (Shoemaker and Reese 1996). The fundamental point of the gatekeeping theory, as developed by Kurt Lewin (1947), is that there are forces or pressures that can either impede or facilitate the flow of news items through the 'gates' (Shoemaker 1996). Kurt Lewin (1947) first used the term 'gatekeeping,' to describe a wife or mother as the person who decides which food finally ends up on the family's dinner table. The gatekeeper is the person tasked with the responsibility to decide what qualifies to pass through each gate section, of which, there are several in the process. Although Lewin's original focus was the food chain, the gatekeeping concept has been applied to how news items meander through some selection processes. In the 1970s, however, McCombs and Shaw decided to study the effects of gatekeepers' decisions and found the audience's appreciation of a news item is premised on the degree of prominence given to it by the media. Early studies on gatekeeping focused on the decisions of individual journalists (Manning White 1950; Snider 1967). However, subsequent research reveal that the work of journalists in the gatekeeping process is also affected by other forces, such as the professional routines of journalists and the influence (or policies) of the news organization (Ettema \& Whitney, 1987 cited in Cassidy, 2006).

\section{News Values}

News values, occasionally referred to as 'news criteria' or 'news factors,' are a conceptual framework used within journalism studies and journalism education to describe the gatekeeping practices of the mainstream news media. Specifically, news values are defined as qualities of events that increase the likelihood of their being covered in the news. In respect of news routines, news factors or values can be seen as a set of selection rules which 
govern journalistic judgments. Galtung \& Ruge, (1965) used the concept, news values in their attempt to explain which particular features, attributed to an event influence journalists' perception and selection of contemporary events as news. The theory of news values proposes that there is a systematic and stable association between the qualities attributable to an event (news factors) and the news value assigned to the respective news item by journalists (Scheufele, 2006 cited in Maier \& Ruhrmann, 2008: 199). Numerous lists of news values exist (Ryan, 1991) and have been generated using a wide variety of methods, including interviews and surveys of journalists, analysis of news coverage, newsroom ethnographies, content analyses of finished news items, and simple introspection by journalists-cum-academics. However, the most widely cited list of news values remains that of Galtung and Ruge (Harcup and O’Neill, 2001 cited in Brighton and Foy, 2007; 2009), which is often credited to be the original list.

Since Lippmann (1990: 23, cited in Eilders, 1996: 1) asserted that there are event characteristics that lend 'news values' to a news item which enhances its chances of being selected for a publication by news media, many lists of news values/criteria have also been suggested by media researchers and journalists beyond those of Galtung and Ruge's. For example, beginning with Östgaard (1965 cited in Eilders, 1996: 1), who meta-analysed several content analyses on the international news flow and found three factors determining selection: simplification, identification and sensationalism; Denis MacShane (1979: 46) subdivided newsworthy events into the following categories: Conflict, Hardship and Danger to the community, Unusualness, Scandal and Individualism. Harcup and O’Neill's (2001 cited in Brighton and Foy, 2007) study of the printed press resulted in their attempt to revise and update Galtung and Ruge's list as the following: Power élite, Celebrity, Entertainment, Surprise, Bad news, Good news, Magnitude, Relevance, Follow-ups and Media agenda. Other examples include Warner 1970; Ruehlmann, 1979; O’Sullivan et al. 1983; Hetherington, 1985; Bell, 1991; Ryan, 1991; Gregory \& Miller, 1998; Herbert, 2000; McQuail, 2000 (cited in Braun, 2009: 16).

It is worth noting that many media and communication researchers have used a combination of Galtung and Ruge's list of news values and the lists of other researchers like Herbert Gans' (1979 cited in Braun, 2009: 16) in their studies and scholarship. 
Thus, the theory of news values is a fruitful theoretical approach for the analysis of the criteria for news selection in both the print and the electronic media, hence its employment in this study.

\section{Review of Related Work}

Many scholars have taken news values-whether those of Galtung and Ruge or other scholars - to be an accurate representation of the news media's selection practices. William P. Cassidy (2006) studied the similarities between online journalists and print journalists in the USA in relation to the gatekeeping and news value concepts as well as the influence of gatekeeping forces at the individual and routine levels on the professional role conceptions of print and online daily newspaper journalists. Cassidy used the survey method and gatekeeping theory and Shoemaker and Rees hierarchical model of news influences, which allows for the study of gatekeeping on five levels of analysis-individual, routine, organizational characteristics, extra media and ideological. His finding was that routine gatekeeping forces exerted more influence on the professional role conceptions of print and online journalists than did individual level forces. In effect, Cassidy (2006) like Ramaprasad (2006:11) says that the media routine has the largest influence on news selection.

However, McGregor (2002) argues that rather than news values, what is selected and presented as news is driven by pictures and their perceptual and iconic power, thus the value of visualization (Maire et al. 2008). To justify that this value is not only valid for television news, McGregor cites Grattan (1998) as noting that most newspapers are increasingly designdriven, therefore design is used to attract readers, especially the young. And that, stories likely to have designs or pictures stand a greater chance of being selected for publication. This was McGregor's finding when he studied newsworthiness in the media in New Zealand to determine contemporary criteria for selecting the news beyond news values. As yet, no single news value has been identified as having more intensity during the gatekeeping process than the other. In the study they carried out concerning the appearance of news on the Congo, Cuba and Cyprus in four Norwegian newspapers, Galtung and Ruge (1965) discovered that when the frequency of an event is related to the frequency of appearance of the news carrier, its chances of becoming news are higher. They concluded that, the more an event satisfies certain conditions, the more easily it will be chosen as a news item. Though 
Galtung and Ruge's (1965) study is dated it is believed to be seminal in the sense that the majority of the studies done on news values use their study as the starting point.

Kalyango (2009:209) corroborates Shoemaker (2006; 1996); Tuchman (1973, cited in Alowo, 2010); Galtung and Ruge (1965) and Cassidy (2006) finding that apart from the media routines (especially assessing news worthiness of news items using news values) there are other forces that influence news selection. In his study to examine political news use and democratic support in Ugandan radio, Kalyango (2009) discovered that the editors' selection of news was greatly influenced by the interest of their listeners. In this regard, editors of newspapers are likely to identify the interest of their readers as an important factor during the gatekeeping process of especially the lead news. Many Ugandans use the media to get information about politics and the government (Kalyango, 2009:209) and this is likely to be the case in Ghana as well. Using the survey method, Okigbo (1990) conducted a study of gatekeeping in the Nigerian press. His study involved 21 senior editors and reporters from four national newspapers (The Guardian, National Concord, New Nigerian and Nigerian Standard.) and the finding is that 'as a concept, gatekeeping holds great promise in African mass communication research’ (Okigbo, 1990:9). Specifically, the study reveals that: (1) gatekeeping operations are affected by corporate philosophies and policies of newspaper organizations irrespective of type of ownership; (2) journalists working in privately-owned newspapers pay less attention to ownership forces in the selection of news; and (3) that prejudice and personal preferences are played down considerably by the journalists. This, however, contradicts Shoemaker's (2006) claim that the more power a person wields the greater his/her chances of selecting, shaping, and otherwise determining what becomes news. In Kurt Lewin's (1947) view, the gatekeeping process, which could also be applied to communication studies, is guided by forces which influence the gatekeeper's decision on either to accept or reject a given news item from getting into a newspaper.

\section{Methodology}

This study used content analysis, in-depth interviews and survey methods to examine the criteria used for news selection at the Daily Graphic. This is what Wimmer and Dominic (2011: 49) termed triangulation, which refers to the use of both qualitative methods and quantitative methods to fully understand the nature of a research problem. 
The purposive sampling technique was employed for the in-depth interviews. The Deputy Editor, Daily Graphic and the General Manager, Newspapers were interviewed. These two persons were selected because they played a vital role in news selection and gatekeeping at the Graphic. A composite week was constructed to get a representative sample for the content analysis. Riffe, Aust, and Lacy (1993, cited in Wimmer and Dominick, 2011: 163) demonstrated that a composite week sampling technique was superior to both a random sample and a consecutive day sample when dealing with newspaper content. For example, a study might use a sample of one Monday (drawn at random from the number of possible Mondays in the month), one Tuesday (drawn from the available Tuesdays), and so on, until all weekdays have been included (Wimmer and Dominick, 2011: 163). The universe was publications of the Daily Graphic spanning January 1 to December 31, 2012. Using the constructed composite week, six editions were selected from each month and that amounted to 72 editions for the sample size (for the content analysis). And 202 news items on the front page were analysed. Neuendorf's (2002, cited in Alowo, 2010: 24) steps of content analysis were used. Consequently, five categories of variables were identified-news prominence, news topics, focus of the news (positive, negative and neutral), type of news and news values In addition to the publications, the journalists, whose by-lines appeared in the news items of the selected sample, were interviewed using a questionnaire. In all, 62 journalists were interviewed using the questionnaire.

\section{Reliability}

Holsti's (1969) formula for determining the reliability of nominal data in terms of percentage of agreement was used:

$$
\text { Reliability }=\frac{2 M}{N 1+N 2}
$$

where $M$ is the number of coding decisions on which two coders agree, and N1 and N2 are the total number of coding decisions by the first and second coder, respectively. Neuendorf (2002, cited in Wimmer and Dominick, 2011: 175) proposes the following guidelines: Coefficients of .90 or greater are nearly always acceptable, .80 or greater is acceptable in most cases, and .70 may be appropriate in some exploratory studies for some indices.

Using Holsti's (1969) formula, a reliability coefficient of .965 was realised. This was calculated as below: 


$$
\begin{aligned}
\text { Reliability } & =\frac{2(195)}{202+202} \\
& =390 / 404=.965
\end{aligned}
$$

Though, this study is likely to lend itself to easy replication, reliability in respect of the survey and in-depth interview results can be challenging in the sense that the respondent are likely to give diverse answers to the open-ended questions and the questions in the interview guide. In effect, varying results might be arrived at. This is likely to affect the degree of the reliability of those results.

\section{News Topics}

A content analysis of 202 news items on the front page of 72 editions of the Daily Graphic published in 2012 showed that news about internal politics emerged the most prevalent news topic (55.4\%) as shown in Table 1 . This was followed by news on crime, law and order (12.9\%). The third most covered news topic was public healthcare and welfare (9.4\%) followed by the category dubbed other (7.9\%). Accidents and disasters (7.4\%) was the fifth most prevalent news topic with education (3.5\%) being the next most common news topic. Military, navy and defence was (0.5\%) while no news was covered on land, entertainment, fashion and beauty on the front page of the Daily Graphic.

Table 1: Frequency of news topics

\begin{tabular}{|lcc|}
\hline Topic & Frequency & Per cent \\
\hline internal politics & 112 & $55.4 \%$ \\
accident and disasters & 15 & $7.4 \%$ \\
military/navy and defence & 1 & $5 \%$ \\
diplomacy and foreign relations & 6 & $3 \%$ \\
public healthcare and welfare & 19 & $9.4 \%$ \\
education & 7 & $3.5 \%$ \\
crime/law and order & 26 & $12.9 \%$ \\
other & 16 & $7.9 \%$ \\
\hline Total & 202 & $100.0 \%$ \\
\hline
\end{tabular}

This Table shows the most covered news topics. $\mathrm{N}=202$ 
A cross-tabulation of news topics and news prominence revealed that although there was some mix of topics, news stories about internal politics, crime, law and order, and public health and welfare and accidents and disasters were likely to be presented more prominently than other topics.

\section{Focus of the News}

Negative news, which encapsulated stories about misunderstanding, conflict, diseases, natural and human disasters, frauds and scandals was given much focus on the front page (48.0\%) of the Daily Graphic. Positive news (news about development, economic growth, easing of tension, harmony and justice) came second (28.7\%) followed by neutral news (23.3\%) as shown in Figure 1.

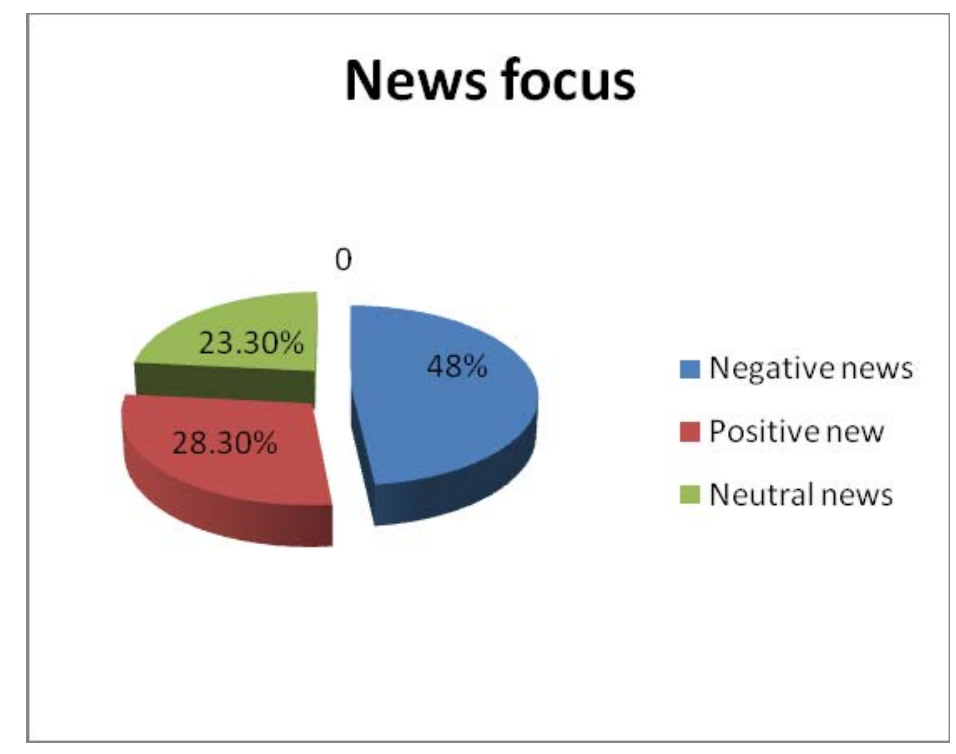

Figure 1: Focus of the news

A cross tabulation of news focus and news prominence showed that about 40 per cent of the lead news had a negative focus (Table 2). This finding supports Hakins‘s (1981:3 cited in Alowo, 2010: 45) observation that negative news is more prominently presented than any other news in both newspapers and television. Again, as observed by Schwartz (2005), negative news was dominant in the lead news because journalists find it easy and simple to write about. 
Table 2: a cross tabulation of news focus and news prominence

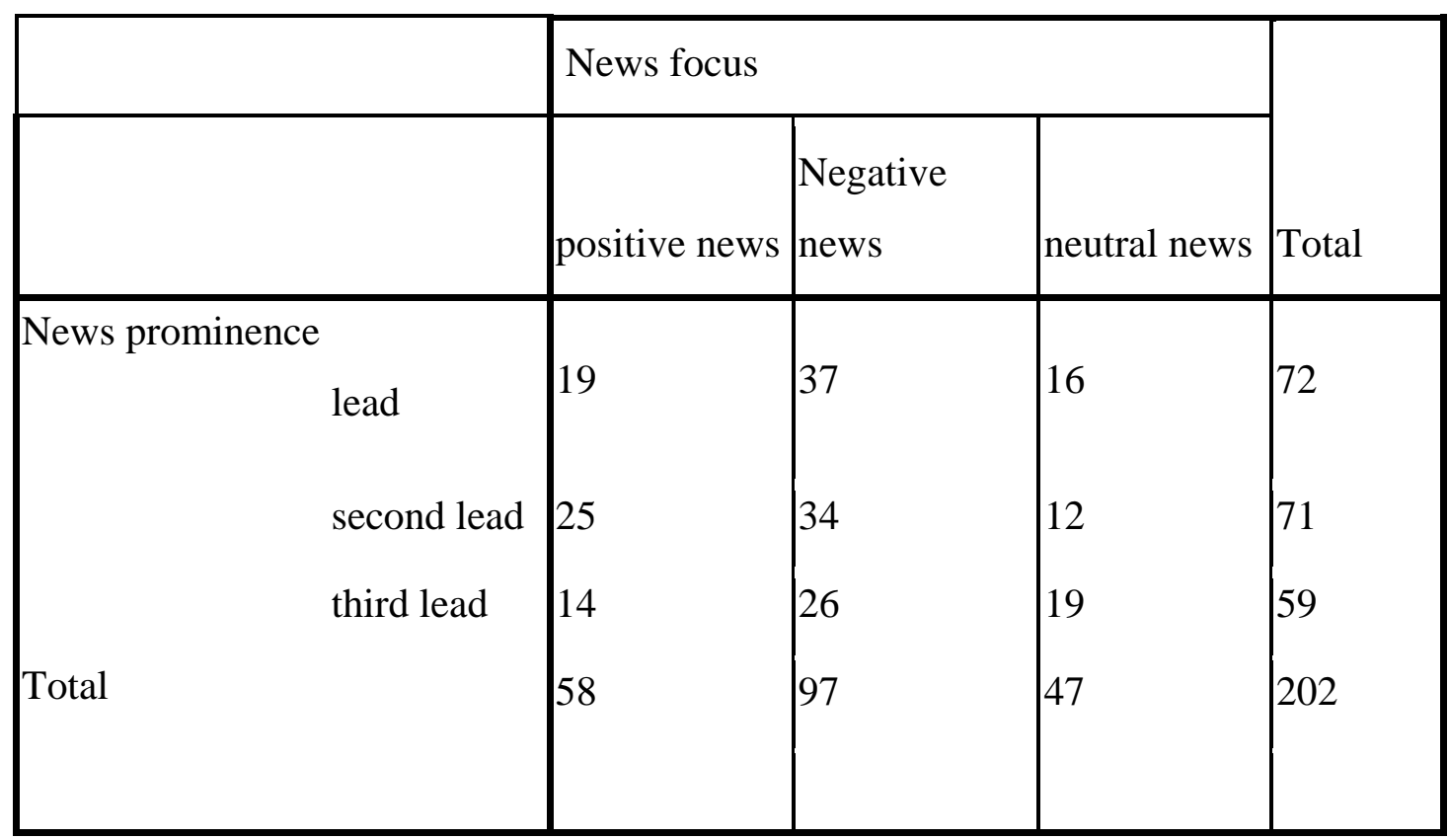

\section{News Type}

The data from the content analysis show that almost nine out of every ten news items (86\%) published on the front page was hard news (see Figure 2). The Daily Graphic which has become synonymous with the Newspaper is a state-owned newspaper considered as an elite newspaper dealing with serious and important matters in and around the country. It is therefore not surprising that the Newspaper concentrated on hard news. According to Strömbäck (2008:19 cited in Alowo, 2010: 46), the media which concentrates most on hard news has a propensity to cover events and activities involving influential people.

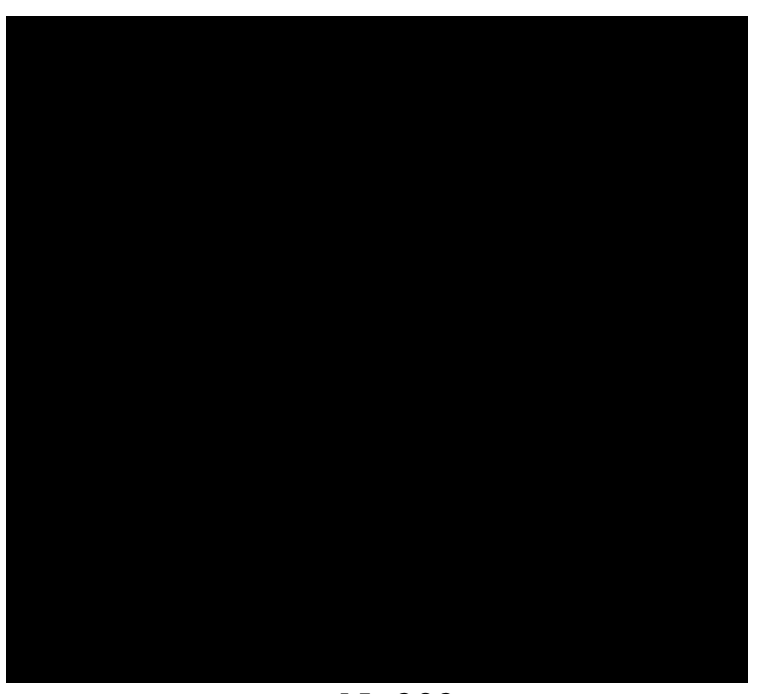

$\mathrm{N}=202$

Figure 2: Showing the most common news type 


\section{The Most Common News Values}

Figure 3 shows that influence (15.8\%), range (15.8\%), prominence (13.3\%), status of location (10.3\%), action (9.8\%) and personalization (9\%) were the six most important news values presented on the front page of the Daily Graphic. The least frequent criteria used to select news were aggression and demonstration with less than two per cent $(1.11 \%)$ and less than one per cent (0.46\%) respectively. As noted earlier by Gans (1979), Galtung and Ruge (1965), Peterson (1979) and Maier et al. (2008) in their study of news values in the Western media, the news presented on the front page of the Daily Graphic during the period under review turned out to be about prominent people like the Late President Mills, leaders of the various political parties, businessmen and women, and heads of institutions who are known in the media circles. Prominence accounted for 13.3 per cent of the news displayed on the front page.

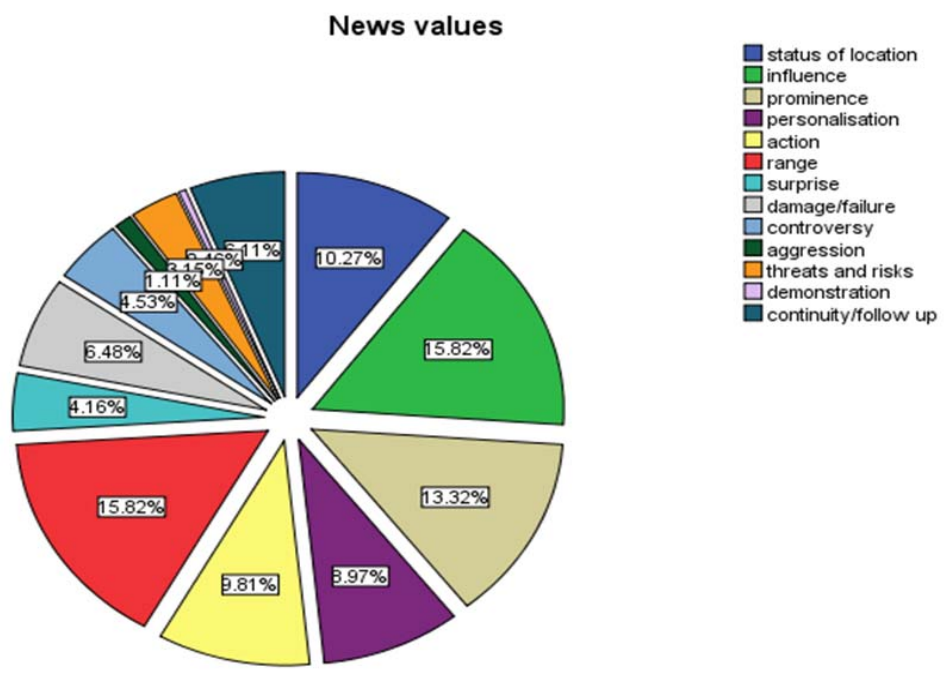

Figure 3: Showing the news values in the news

This chart represents the percentages of news values in news. Note: sexuality/eroticism as a news value was not presented on the front page.

\section{News Values and News Prominence}

The research was also conducted to establish the correlation between the number of news values in a given news item and its prominence (how it is presented on the front page). The study found that each news item on the front page had an average of five news values (see 
Figure 4). Even though a news item should embody an average of five news values for it to be published on the front page, a news item did not have to possess the highest number of news values to become the lead. As indicated by Figure 4, a news item with one or two news values could be chosen as the lead depending on the prevailing atmosphere in the society and the gatekeepers' decision.

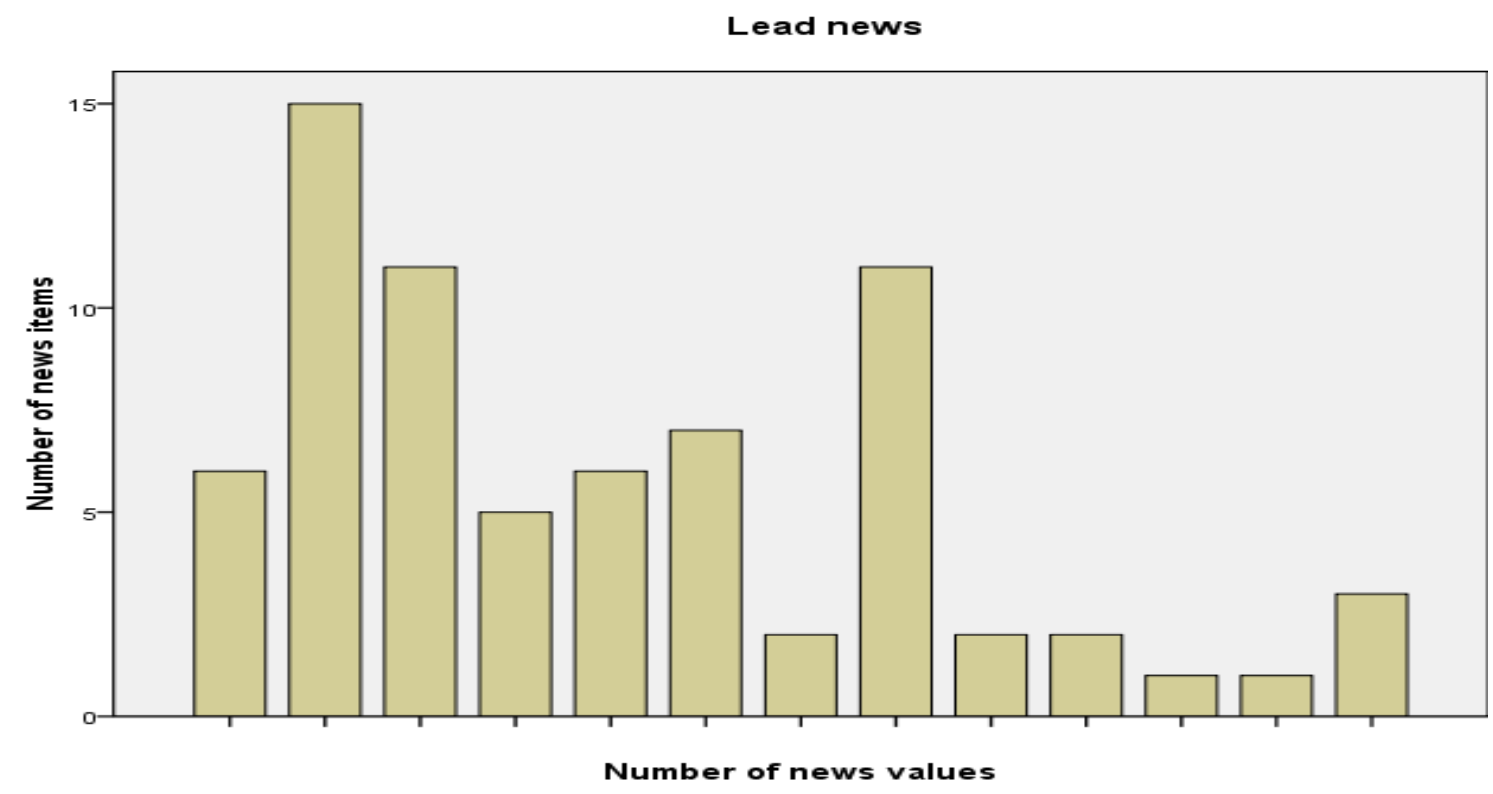

Figure 4: Showing the number of news values in lead news

This chart represents the number of news values in the lead news. $N=72$

\section{Is there Any Specific Guidelines Influencing News Selection at The Daily Graphic?}

The 62 journalists were asked to indicate whether there was any written document guiding the selection of news at the Daily Graphic and how that affected them in their work. Ninetyfive per cent of the respondents answered in the negative. Five per cent (5\%), however, indicated that there was an editorial policy which governed how the "final news" was selected for publication. This revelation of the "final news" being decided at an editorial meeting is consistent with the General Manager, Newspaper and Deputy Editors' submission that news selection at the Daily Graphic is generally open, however, what finally comes out or is published on the front page is determined at an editorial conference held every day. In effect, news selection at Graphic is left to the discretion of the reporters and the writers but what is finally allowed through the 'news gate' is a product of editorial role. 


\section{Why Certain News Items are Presented Prominently}

Editorial decision makers or news processors were asked to explain why they select and present certain news items prominently and not others. Results from the interview revealed that generally, a high number of news values a given news item embodies were important elements that influenced the decisions of the editors. The respondents noted that for a given news item to become the lead news, it must affect a big number of people (RANGE), be timely, unexpected (SURPRISE) and also have the attributes of controversy and conflict. For instance one of them argued that:

'A news item may be the lead if it affects many people because at Daily Graphic, our aim is to help with the development of Ghana and so anything that we see contributing to the development of the country that is what will go.'

(Editor 1)

This submission by the editor suggests that there are times that a news item need not have so many news values to become the lead story. This revelation supports the finding from the content analysis that there were times that news items with least news values became the lead news (see Figure 4). The study also found that there were no specific written down policy guidelines for the selection of lead news.

We do not have specific written down policy or guidelines for lead stories. [...]This idea of using the biggest font and so on [...] sometimes may not even matter so much. A story might be very small in the corner but the way it is treated it may be even important than the one with the biggest font. So, there is no written policy to guide news selection.

(Editor 1).

The editors indicated that whatever policy guidelines that they have were for the general operations of the newspaper and not for news selection.

It is interesting to know that differences in font size do not necessarily mean news prominence (news item displayed prominently in the newspaper). Perhaps this also forms part of what Hasty (2006: 74) referred to as 'the house style of the newspaper [the Daily Graphic].' So, as Shoemaker notes,

Underlying the general understanding of what, within a culture, will become news is a long list of factors and influences, and newsworthiness is only one of these. We should no longer use the prominence with which events are covered as a measure of 
the event's newsworthiness, and our theories should not use newsworthiness as the sole (or even an important) predictor of what becomes news.

(Shoemaker 2006:111)

The editors noted that news values such as timeliness, controversy, bizarre, prominence magnitude and novelty are among the most commonly accepted news values.

We do not have documented news values that determine news selection here. Generally, it is about the traditional ones- timeliness, controversy, bizarre, prominence and magnitude. We do not depend on one particular value ... what is important is what we have on our table on a particular day.

(Editor 2).

This revelation is consistent with the findings by Eilders (1996); Braun (2009); Galtung and Ruge (1965) that among the most common news values a given news item embodies are timeliness, controversy, bizarre, prominence, magnitude and range. The finding is also consistent with the journalists' assessment of the most important news values the lead news should have and the topics they prefer to be the lead news (see Table 3).

Therefore, there is the likelihood that news gatherers submit stories which are in the taste of the editors. And the news stories which eventually become the lead reflect the newsworthiness editors attach to them (Shujun, 2008: 9 cited in Alowo, 2010: 65).

Table 3: Importance of news values (\% of journalists saying extremely important)

\begin{tabular}{|l|l|}
\hline & \\
News values & News gatherers (\%) \\
\hline status of the location & 60.00 \\
Influence & 80.00 \\
risks and threat & 55.00 \\
Prominence & 70.00 \\
personalisation & 20.00 \\
Concreteness of activity & 60.00 \\
range & 85.00 \\
\hline
\end{tabular}




\begin{tabular}{|l|l|}
\hline surprise & 40.00 \\
damage/failure & 40.00 \\
controversy & 60.00 \\
aggression & 40.00 \\
Continuity & 65.00 \\
Sex & 0.00 \\
\hline
\end{tabular}

The editors revealed that besides lack of stringent editorial policy, no governmental pressures influence their news selection. In other words, in spite of the fact that the Daily Graphic is a state-owned newspaper, its operations are entirely private and that ownership is not a factor considered in news selection. Elaborating on the issue of other factors, including ownership, affecting news selection in the media, one of the editors had this to say:

'No! No! No! We don’t. You see, May-be years, years ago. We have moved away from the situation where the thing is coming from government so it's got be on the front page. That was a long time ago. We are mindful of the fact that being a national or state-owned newspaper we cannot go sensational so we have to present the fact as they are. So we see news as that which will be of interest to the general public-things that will generally develop the nation'

(Editor 2).

From the above submission, it can be argued that the Daily Graphic focuses on hard news (news on important and serious matters such as politics, business, and economy). This further explains the absence of the news value of sex (celebrities and their lifestyle and entertainment) in the content analysis and the survey.

Gender was also not identified as an important news factor in the case of the Daily Graphic. However, there are peculiar circumstances that might account for news about gender being displayed on the front page.

Gender actually doesn't influence news selection at the Graphic but as we are in a male dominated society if naturally something happens to a woman it is felt it has a lot of societal impact. So, if for instance, a man butchers the wife, it is something that is of societal importance and it will be considered for the front page.

(Editor 2). 


\section{Discussion}

It is necessary to note that the study intended to examine what determines news selection at the Daily Graphic especially in the face of so many news stories that come up each day. Specifically, news values concept and the gatekeeping role of the editor were considered in establishing the impact of these two concepts on news selectivity criteria at Graphic.

The results obtained reflect the content of the news stories given importance or presented prominently in the Daily Graphic. Generally, news about politics which included legislative activities, Executive activities, Judicial decisions, constitutional issues, elections, political fundraisings and donations, statements and activities of individual politicians, political appointments, interparty relations, activities of interest groups, pubic opinions pools, abuse of political power and corruption, dominated the front page of the Daily Graphic. This was followed by crime/law and order and public healthcare and welfare. A cross-tabulation of topics and news prominence revealed that while all news topics can be the lead news, internal politics was the most likely topic to be presented prominently. Even the editors' disclosure that the lead news need not have the highest number of news values but rather it should be of public interest and contributes to national development is a clear indication that news stories about politics will be selected as lead news since they usually affect the generality of the Ghanaian populace. The domination of the front page of the Daily Graphic by political and crime and disaster news accentuates the finding of a study by Stempel (1985 cited in Alowo, 2010: 47) on the mix of topics and the selection of stories which found that topics also influence the selection and presentation of news in the media. According to Shoemaker and Cohen (2006:11), people tend to pay more attention to deviant individuals and acts hence, their frequency on the front page. The dominance of politics could be partly due the fact that 2012 was an election year and naturally issues about politics were expected to dominate the media landscape. However, Hartley (1982 cited in Alowo, 2010: 47) asserts that the prominence of the people involved in such news may partly account for its frequency because of the assumption that actions of illustrious people (e.g. the president, ministers, Parliamentarians, lawyers, judges and leaders of political parties) are more consequential than the activities of ordinary people.

News about crime, law and order was also prevalent on the front page and this was followed by internal politics. There are two reasons that may account for the frequent publication of 
crime news. First, the beat system, which involves journalists specializing in certain topics, partly explains this pattern of news coverage at the Daily Graphic. News on crime, law and order dominated the front page because this kind of news is not too difficult to obtain or deal with. For instance, records of criminal cases can easily be obtained from the police and by following criminal court proceedings. In addition to this, crime news is usually negative and people turn to be much attracted to bad news.

Negative news dominated the lead news. The reason for this kind of coverage can be attributed to Shoemaker and Cohen's (2006:11) observation that people pay less attention to good news than to bad news and that people tend to remember negative news more than positive news (Strömbäck, 2008:32 cited in Alowo, 2010: 68).

Hard news dominating the front page was not unexpected because the Daily Graphic is regarded as an elite newspaper. In fact, the paper has a number of inside pages earmarked for what Lehman-Wilzig and Seletzky (2010) categorized as soft news. Besides this, the Fridays and Saturday editions also carry more soft news. This explains in part why such news is not published on the front page. According to one of the editors, the Newspaper focuses on soft news on Fridays and Saturdays because people usually would want to relax on such days and they would not want anything so serious or hard.

I can tell you that, [...] when selecting stories for Fridays and Saturdays; we always have it that as a weekend, we have to give things that are as you called it soft. For example, if a man goes to steal so that he can marry another woman, it will be selected because we feel that people need to rest or relax and enjoy themselves....

(Editor 1).

Both news gatherers and editors highly value the ability of the lead news to influence social change by holding the government accountable to its citizens. This indicates the commitment of the newspaper's role in promoting transparency. Because of the limitations of time and space, selection of content is a necessary function dispensed by editors. The evaluation processes are influenced by several factors of which news values is the most essential. All the news values the journalists regarded as extremely important were among the factors most widely cited as criteria for news selection-timeliness or novelty, importance or impact, influence, prominence, unusualness, conflict or controversy (see Table 3). Both news writers and processors indicated that controversy, prominence, surprise (unusualness) and range 
(impact or importance) were vital attributes in the lead news. From that point of view, it could be argued that all the journalists irrespective of their location exercise similar news values or have the same standards for the lead news.

\section{Conclusion}

Both gatekeeping theory and news values theory make it clear that not all the news items available to editors are published in the newspaper. News stories go through a complex process of inclusion and exclusion of stories which was perceived as a gatekeeping process by earlier scholars. During this process for instance, news gathering, writing, shaping, sorting and presentation, news gatherers or news processors use news values as guidelines as argued by Golding and Elliot (1979):

'...the criteria of selection from material available to the newsroom of those items worthy of inclusion in the final product...they are guidelines for the presentation of items, suggesting what to emphasize, what to omit, and where to give priority in the presentation of the items to the audience.'

(Golding and Elliot, 1979: 114 cited in Alowo, 2009: 73)

However, much as news values are important in the gatekeeping process, they do not necessarily guarantee the selection of a given news item for publication. This is because the process is influenced by several factors and pressures. Such factors include but are not limited to the interests of the public, news organization (e.g. 'house-style'), national developmental agenda, day and/or time of publication and the type of its ownership (in some media organisations). 


\section{Reference}

Alowo, Maryian (2010). News in the Ugandan Press: The Case of the New Vision. Master's thesis, Örebro University.

Braun, J. A. (2009). Rehashing the gate: News values, non-news spaces, and the future of gatekeeping. Master's thesis, Cornell University.

Cassidy, W. P. (2006). ‘Gatekeeping similar for print, online journalists’. Newspaper Research Journal, 27:2, pp. 6-23.

Clayman E. S. Reisner A. (1998). 'Gatekeeping in action: Editorial conferences and assessments of newsworthiness', American Sociological Review, 63:2. p. 178.

Donohue, George A., Phillip J. Tichenor and Clarice N. Olien. (1972). 'Gatekeeping: Mass Media Systems and Information Control’. F. G. Kline and P. Tichenor (eds). Current perspectives in mass communication research, Beverly Hills CA: Sage, pp. 41-70.

Eilders, C. (1996): The role of news factors in media use. Discussion Paper FS-III 96-104. Berlin: Wissenschaftszentrum, Berlin, URL: http://bibliothek.

Gadzekpo A. (2007). ‘Fifty years of the media’s struggle for democracy in Ghana: Legacies and Encumbrances.' Ghana Studies v.10 (2007). pp. 89-106.

Galtung, J., \& Ruge, M. H. (1965). 'The structure of foreign news: The presentation of the Congo, Cuba and Cyprus crises in four Norwegian newspapers', Journal of Peace research, 2:1, pp. 64-90.

Hasty, J. (2002). 'Ghana press: radio, TV and newspaper', htt/www.pressreference.com/forum. Accessed 30 September 2013.

Hasty, J. (2006). Performing power, composing culture: The state press in Ghana. London: Sage Publications.

Kalyango, Y. (2009). 'Political news use and democratic support: A study of Uganda's radio impact', Journal of Radio \& Audio Media, 16: 2, pp. 200-215.

Lewin, K. (1947). 'Frontiers in group dynamics II: Channels of group life; social planning and action research'. Human Relations, 1, pp. 143-153.

Lehman-Wilzig, S., \& Seletzky, M. (2010). 'Hard news, soft news, general news: The necessity and utility of an intermediate classification'. Journalism, 11:1, pp. 37-56.

MacShane, D. (1979). Using the Media. London: Pluto Press.

Maier, M, Ruhrmann, G \& Karin, S. (2008). 'Celebrities in Action and Other news: News factors of German TV News 1992-2004'. Human Communication, The Pacific and Asian Communication Association, 11:1, pp. 197-214 
McGregor, J. (2002). 'Restating news values: Contemporary criteria for selecting the news’. ANZCA 2002 Online Journal.

Okigbo, C. (1990). 'Gatekeeping in the Nigerian press'. African Media Review, 4:2, pp. 1-10.

Schwarz, A. (2006): The theory of newsworthiness applied to Mexico‘s press. How the news factors influence foreign news coverage in a transitional country, Communications, 31:1, pp. 45-64

Shoemaker, P. J., \& Cohen, A. (2006). News around the world. UK: Routledge.

Shoemaker, P. J. (2006). 'News and newsworthiness: A commentary'. Communications, 31:1, pp. 105-111.

Shoemaker, P. J., \& Reese, S. D. (1996). Mediating the Message: Theories of Influences on Mass Media Content. USA: Longman.

Shoemaker, P. J. (1991). Gatekeeping (Communication Concepts). Thousand Oaks CA: Sage.

Kunczik, M. (1988). Concept of Journalism. North and South, Friedrich-Ebert-Stiftung.

Shoemaker, P. J. (1996). 'Media gatekeeping’. In M. B. Salwen, \& D. W. Stacks (eds.), An Integrated Approach to Communication Theory and Research. Mahwah, NJ: Lawrence Erlbaum. pp. 79-91.

Snider, P. (1967). “' Mr. Gates” revisited: A 1966 version of the 1949 case study’. Journalism Quarterly, 44 : 3, pp. 419-427. 